Marko Milojević ${ }^{1}$

University of Singidunum,

Faculty of Business Economics

Ivica Terzić ${ }^{2}$

University of Singidunum,

Faculty of Business Economics
SCIENTIFIC REVIEW ARTICLE doi:10.5937/ekonomika1503173M

Received: June 9, 2015

Accepted: July 10, 2015

\title{
LIQUIDITY OF LARGE COMPANIES IN THE REPUBLIC OF SERBIA
}

\begin{abstract}
The purpose of this paper is to investigate the impact of liquidity on large companies (LC). Liquidity ratios are indicative of the company's ability to pay its due debts and therefore are a good indicator of its current financial performance. The sample used in research consists of financial statements of 794 companies prepared for the period 20072013. During the observed period, the share of current assets in the company's total assets recorded a decline which means that fixed assets have a faster growth rate than current assets. The results obtained indicate that managers minimize the value of supplies within the structure of current assets. Calculated values of liquidity ratio are not compliant with applicable theory which leads us to conclusion that the companies classified as large companies have poor and insufficient coverage of short-term liabilities with current assets. However, ratio shows the positive trend and the first signs of recovery of large companies in regard to liquidity. Analysis of the companies per industry shows that not all companies were equally affected by the economic crisis. Entertainment industry and craft industry are the most liquid one while the construction industry is the least liquid.
\end{abstract}

Key words: structure of company's operating assets, current assets, liquidity ratios, supplies, cash, financial management.

JEL classification: G32, G33, M40, M41

\section{ЛИКВИДНОСТ ВЕЛИКИХ ПРАВНИХ ЛИЦА У РЕПУБЛИЦИ СРБИЈИ}

\begin{abstract}
Апстракт
Сврха овог рада је испитивање утицаја ликвидности на велика правна лища. Pauиju opšte i redukovane likvidnosti показују способност компаније да сервисира своје доспеле обавезе, па су стога, врло добар показатељ тренутног положаја и индикатор финансијског стања. Узорак на којем је вршено истраживање чине финансијски извештаји 794 компаније за период од 2007-2013. год. Током
\end{abstract}

\footnotetext{
${ }^{1}$ mmilojevic@singidunum.ac.rs

2 iterzic@singidunum.ac.rs
} 
посматраног периода удео обртних у пословним средствима опада што указује да стална средства расту брже од обртних. Добијени резултати указују да менаиери минимизирају вредност залиха а теже повећағу салда готовине и готовинских еквивалената. Ово за последииу има промену у структури обртних средстава. Израчунате вредности рацииа ликвидности нису у складу са оним што прописује теорија па то упућује на закључак да компаније, које су по српском закону о рачуноводству разврстане као велика правна лица, у већини случајева имају лошу и недовољну покривеност краткорочних обавеза обртним средствима. Ипак тренд кретања ращија је позитиван и указује на прве знаке опоравка великих предузећа са становишта ликвидности. Класификащија по делатностима показује да нису све делатности подједнако осетиле утииај економске кризе. Стручна, научна, иновачиона и техничка делатност је најликвиднија а делатност грађевинарства је најнеликвиднији.

Кључне речи: структура пословних средстава, обртна средства, ращиа ликвидности, залихе, готовина, финансијски менаимент.

\section{Introduction}

Economic crisis, the roots and origins of which can be traced back to 2007 in the United States (USA) left visible effects on the businesses and economy of the Republic of Serbia (RS). The overheating of the US real estate market, caused by mortgage loans and subprime loans, quickly migrated to European markets. The cause of the crises lies in insatiable greed, desire to earn millions in fees and to secure higher profits for global investors from huge available resources which today can be measured in billions of dollars (Vujević, 2010; Kostić \& Kostić, 2014). In Serbia, the opinion is that the first effects of the economic crisis were felt in the second half of 2008 when the volume of trading of the Belgrade Stock Exchange plummeted. The trading volume was cut by half of the regular volume and the number of transactions almost by a third. This situation spread to other economic activities.

Economic crisis resulted in the change of short-term strategy implemented by a large number of companies. Faced with reduced economic activity, the companies turned to the strategy of moderate profitability, in order to preserve liquidity. This system is referred to as ProfitabilityLiquidity (PL) and was developed in Germany. The roots of this business management system lie in the ratio system developed by the Economic Committee of the Central Association for Electro-technical and Electronic Industry in Germany (ZVEI) (Marjanović \& Milojević, 2012).

PL system is focused on a relatively small number of ratios (indicators) and the key part of the system is represented by profitability ratios and liquidity ratios. The profitability ratios are focused on regular business results which are derived from income and expenses. Contrary to that, liquidity is not a primary goal, but an inevitable prerequisite for company's good operation. Based on regular comparison of projected and actually values, PL System offers insights important for decision making process both on an annual basis and within shorter periods. This system of financial ratios is composed of two parts, general and special (Marjanović, Milojević \& Simeunović, 2011). From the perspective of our research, a special PL system is of interest to us because it takes into account the special features of individual 
industry and individual company and therefore it is suitable for analysis and planning i.e. more helpful in making business decisions (Reichmann, 2006).

Ratios which provide insight into profitability are as follows: gains (loss), rate of gross, operating and net income ${ }^{4}$, return on net operating assets. The portion of the PL system which refers to liquidity comprises value monitoring: current, reduced and quick ratio as well as monitoring the movement of net working assets (NWA). Based on monitoring of these ratios, financial managers are able to reach high quality decisions which will reflect on the company through improvement of both current and long-term business performance (Vukašin \& Anđelković, 2014).

The goal of this paper is to understand the manner in which companies, classified as large companies pursuant to the Serbian Law on Accounting, manage their liquidity. Based on the values and movement of ratios, we shall attempt to evaluate how LC in RS reacted to the economic crisis and what business strategy was implemented by their management in order to adapt to new market circumstances; whether the management tended to increase or decrease current assets in crisis i.e. whether the structure of current assets was subjected to change. Maintaining financial stability and observing the rule of financing is directly related to liquidity and represents a precondition for normal operation of a company (Barjaktarović, Milojević \& Terzić, 2014). Likewise, it is interesting to find out whether the crisis had the same impact across all industries or whether it had more impact on individual sectors (Božilović \& Miletić, 2014). For this purpose, the following general hypothesis was formulated:

- In the circumstances of economic crisis, companies focus their attention to monitoring and maintenance of liquidity ratios in line with values prescribed by theory.

We shall attempt to prove or refute this general hypothesis by using auxiliary hypotheses:

- During the observed period, current assets are subjected to changes and restructuring in an attempt to improve liquidity.

- Current liquidity ratio (CLR) and reduced liquidity ratio (RLR) in large companies were in line with the ratios prescribed by theory, and in times of crisis, the values of these ratios increased.

Our research was conducted on a sample of 794 companies, classified as large companies pursuant to the Serbian Law on Companies. A large company, according to the Serbian Law on Companies, is a company which a) has more than 250 employees; b) has operating income of more than RSD 4.233,5415; c) owns total assets worth more than RSD2, 116,770 (Serbian Business Registers Agency - SRBA, 2014). The reason why we chose large companies is because in 2007 they employed 428,073 people, i.e. $38.62 \%$ of the total number of employees. The documents used in the analysis are the financial statements of this group of companies for the period 2007-2013 obtained from SBRA. In order to manage the data more easily and efficiently, they were converted to Excel sheets and organized in pivot tables. Not all large companies were included in the sample on account of the date when the collection of financial statements started (2009). This is the year in which certain number of large companies ceased to exist or they were classified as middle-sized companies due to reduced operating income or operating assets. 


\section{Results and discussion}

We started the analysis of liquidity by comparing cumulative positions of assets and liabilities of 794 large companies in the Republic of Serbia with the aim to gain insight into their mutual relationship and the observance of the rules of financing. Insight into mutual relationship between the assets and liabilities should show which item in the Balance Sheet (BS) is the key factor in company's operation, i.e. which item is considered most important by these companies and in which they invest most of their available monetary resources (Wells, 2011; Mihajlović, Stanković \& Nikolić, 2014). The second part of this analysis, dealing with the fulfillment of the rules of financing, should enable us to conclude whether large companies comply with the theoretically developed rules which have been confirmed in practice. Golden balance rule, in its strict sense, requires that the current assets are partially financed from long-term sources of financing, i.e. that the current assets exceed the short-term liabilities (Kieso, Weygandt \& Warfield, 2013). It will be interesting to learn if the Serbian companies complied with this rule at the times of economic crisis.

Chart 1: Ratio of cumulative positions on the Balance Sheet in the period 2007-2013

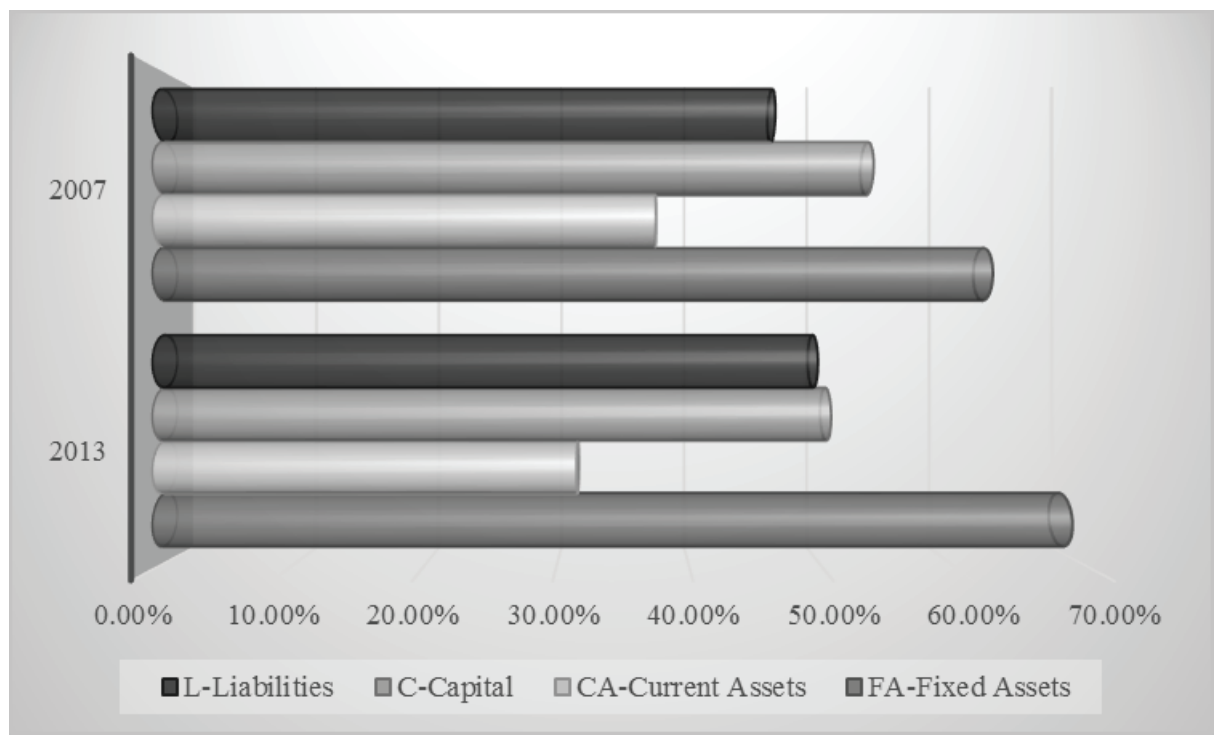

Source: Calculated by the authors

Based on the (Chart 1), we may conclude that the share which current assets have in total assets recorded a downward trend from 2007 to 2013. Most of "available assets", in the course of the life cycle of a company, are invested in fixed assets and they exceed individual values of current assets, capital and liabilities. During the observed period of seven years, fixed assets recorded growth by $9.48 \%$ and liabilities by $6.82 \%$, while the current assets dropped by $15.79 \%$ and capital by $5.89 \%$. This is a negative trend and it confirms that the economic crisis did affect the operation of large companies. 
Chart 2 shows the balance between the assets and liabilities in 2013. This chart is important because it reveals and points out one important fact which is the following: the golden rule of balancing assets and liabilities was not complied with in its strict sense. Fixed assets have not been financed entirely from long-term sources of financing, and one portion of fixed assets was financed from short-term liabilities, and this implies that short-term liabilities exceeded current assets. This is extremely bad because sources of financing were not harmonized with the invested assets in respect of the period of availability and in their amounts. In regard to this, failure to comply with this rule raises a question of liquidity, i.e. opens up a possibility for the companies to come into a situation where they are unable to service their debts regularly due to such structure of assets and their sources.

Chart 2: Balance Sheet for 2013 - Determining Rules for Financing.

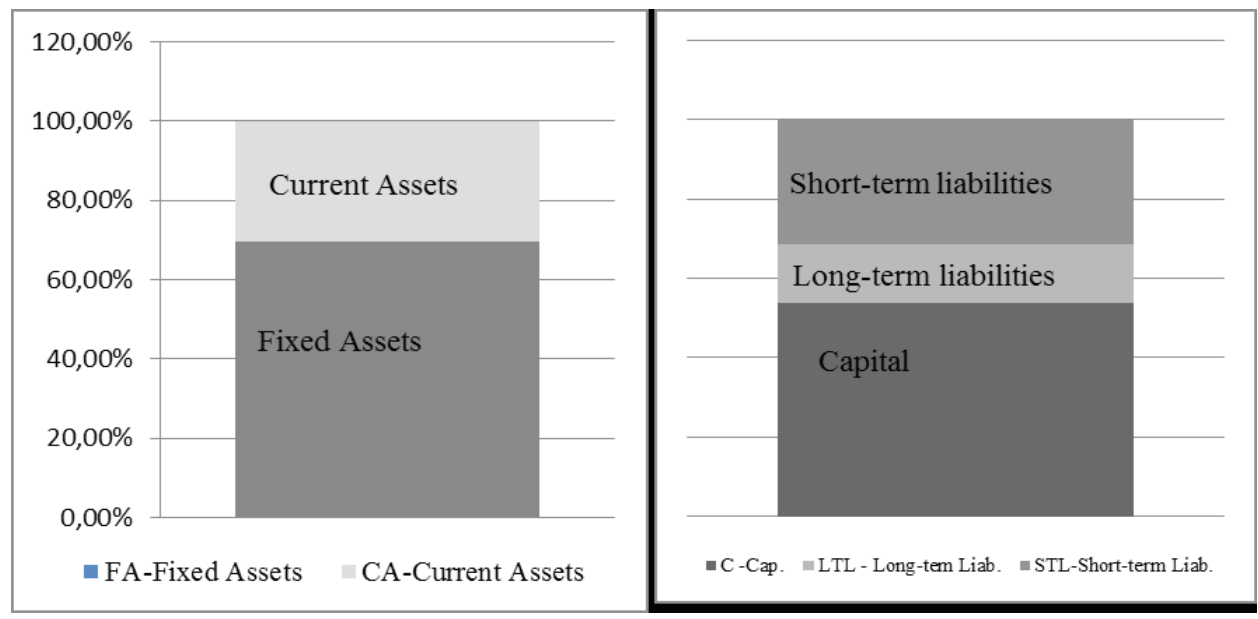

Source: Calculated by the authors

\section{Structure of fixed assets}

If we divide the total assets into two large groups of fixed and current assets, we notice certain regularities. In 2007 and 2013, cumulative fixed assets exceed the current assets. In 2007, current assets had a share of 38\% in the total assets while in 2013 they had a share of $32 \%$. During the observed period, current assets have increased by almost $20 \%$. These ratios lead us to conclude that in the said period of seven years, the share of current assets in total operating assets had recorded a downward trend. It may be interpreted that the reason for decline in current assets is the economic crisis and that it is a result of the sudden growth of fixed assets (Milojević, 2013).

An increase in the total amount of current assets may have either positive or negative impact. A positive impact is achieved in the case of growth of the value of supplies, cash and even receivables under condition that the deadline for collection is getting shorter. Insight into the structure of current assets in large companies led us to conclude that, during the observed period, the value of cash, supplies and receivables was increased by $15 \%$ to $31 \%$. 
For this reason, we calculated the average time required to collect receivables. In 2008, the average time required to collect receivables was 71.81 days and in 2013, it was 86.24 days. Data show that the average amount of time needed to collect receivables was significantly slowed down over the period of seven years, i.e. by $20.09 \%$, which is a negative trend and indicative of how the cash cycle in large companies was slowed down. These data gain even more significance when the structure of current assets is taken into account. Current assets have a predominant share in receivables with $57 \%$, followed by supplies with $38 \%$ and cash with $5 \%$. If we compare these data with the situation in 2007, we may conclude that the share of receivables and cash was increased by $15.12 \%$, i.e. by $4.86 \%$ while the value of supplies was reduced by $2.53 \%$ (Chart 3 ).

Chart 3: The breakdown of current asset for the period 2007-2013

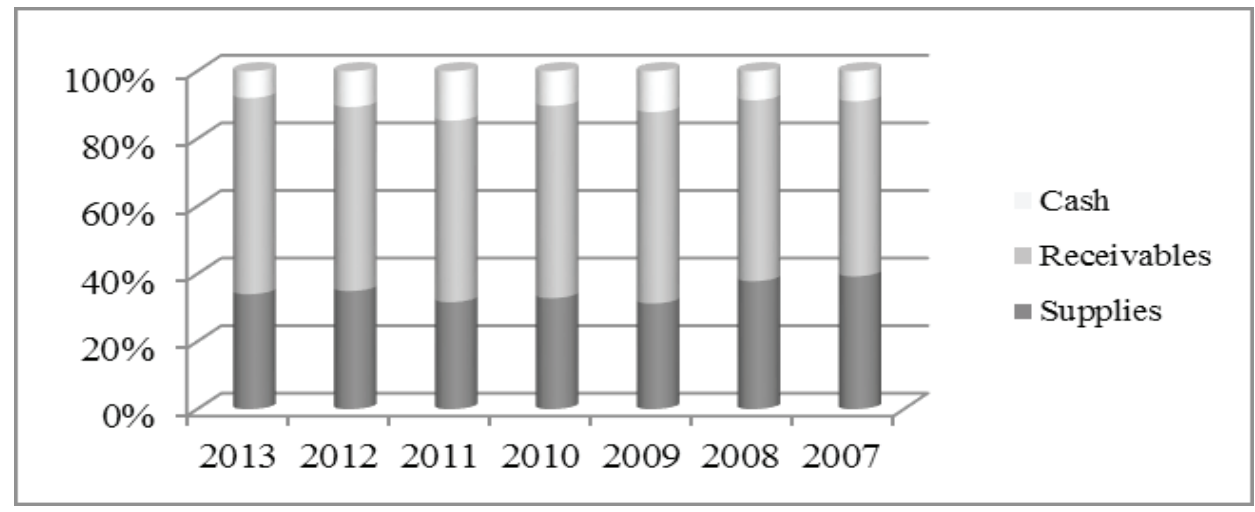

Source: Calculated by authors

Based on results obtained, we may observe that the first auxiliary hypothesis was been proven i.e. that the significant change occurred in the structure of current assets over the observed period. A positive fact to be understood from this is that the cumulative sum of current assets has grown which is counteracted by the negative fact which is that current assets have slower growth rate than fixed assets. Receivables have grown and the number of days required to collect them have increased and we may note that large companies are yet to bring their business performance to the level they recorded in 2007. This result is considered very important and speaks of the impact of economic crisis on the businesses in the Republic of Serbia. The supplies are thinner in the structure of current assets while the amount of cash increases, which proves that large companies have found recourse in the strategy of increasing monetary assets and minimizing supplies.

\section{Liquidity ratios}

The purpose of liquidity ratios is to show the capability of a company to settle, i.e. service its debts within their maturity period while taking care to maintain the necessary structure of its assets (Barjaktarović, Jović \& Milojević, 2013). The two most famous ratios are: current liquidity ratio and reduced liquidity ratio ${ }^{5}$. Theory and 
practice have developed normal values for these ratios which are as follows: CLR $=2$ and RLR=1 (Knežević \& Mizdrakovic, 2010; Nigrini, 2011). One should be cautious when interpreting these ratios, but their purpose is to determine how many monetary units of current assets or what portion of current assets are covered by one unit of short-term liabilities.

Data presented in the table 1 show that the CLR in 2007 was 1.08 which is significantly lower than normal value (2). One monetary unit or one Euro of shortterm liabilities is covered by 1.08 monetary units /euros of current assets. Even though these results are not compliant with the prescribed rule, they indicate that the current assets in this year have been higher than the short-term liabilities and that the companies were able to completely settle their short-term liabilities with their total current assets. When interpreting these values, one should take caution because the sample includes the companies from various industries. In the period 2008-2013, this ratio recorded a continuous downward trend. In 2013, CLR was 0.94 which is lower than its value in 2007 by $14.89 \%$. Continuous reduction of the value of this ratio is indicative of the fact that short-term liabilities have grown compared to current assets. In the period 20112013, short-term liabilities exceeded current assets which was exceptionally bad. It leads to the conclusion that large companies are unable to service their debts from current assets which, de facto, causes the liquidity crisis of the entire economy and slows down economic activity in the country.

Values of RLR were used to determine whether the companies can cover their short-term liabilities with current assets (cash, cash equivalents and receivables) (Barjaktarović, 2009). Unlike CLR, this ratio excludes the most illiquid portion of the current assets, which are supplies. Supplies, as one of the most controversial balance sheet item, are excluded from this ratio because we have been witness to many abuses of this item in the past (Manning, 2005; Coderre, 2009; Schilit, \& Perler, 2010). In 2007 , the value of RLR was 0.78 , which is lower than the normal value of 1 . This year, one euro of short-term liabilities is covered with 0.78 euros of liquid assets. This is not very worrying when the CLR for this year (1.08) is taken into account. A large portion of short-term liabilities was covered with liquid assets and the remaining portion was covered with supplies. Unlike CLR value, which recorded mild but the stable downward trend during the entire period from 2007 to 2013, the RLR recorded a cyclic trend. In 2008 , this ratio was 0.70 , which was a drop from the previous year of $10.26 \%$. At the end of 2009 and 2010 , the ratio recorded a symbolic growth by $1.43 \%$ i.e. $1.40 \%$. The interpretation of the values of these ratios is rather interesting since these ratios point to the fact that despite the economic crisis, large companies in Serbia recorded small but noticeable progress in raising their liquidity level. In 2011, this ratio recorded a more significant drop of $4.16 \%$. The boost of economic activity in this period had no effect on the increase in liquidity, but, on the contrary, led to its decline. The drop in liquidity could be explained with the fact that the year under analysis was a pre-election year, and that the state was the main engine of economic activity, and having in mind that the state was late in settling its liabilities, it reflected on the liquidity of the largest number of companies who do have a business relationship with the state. In 2012, this ratio drops another $2.90 \%$, and in 2013 , if records an increase by $2.99 \%$.

Based on the results of financial ratios regarding liquidity, we may note that our second hypothesis is refuted i.e. that the movement of liquidity values in the observed period is much 
different from what is prescribed by theory. The effect of economic crisis is evident, but what may be interpreted as the positive sign is the fact that in 2013, the analysed ratios recorded increase compared to previous year. However, the comparison of these results with the base year confirms the previous statement that the business performance of large companies has not yet reached the performance level recorded in 2007.

Table 1: Overview of liquidity ratios for the period 2013-2007.

\begin{tabular}{|l|c|c|c|c|c|c|c|}
\hline Ratio & 2013 & 2012 & 2011 & 2010 & 2009 & 2008 & 2007 \\
\hline CLR & 0.97 & 0.95 & 0.97 & 1.00 & 1.00 & 1.01 & 1.08 \\
\hline RLR & 0.69 & 0.67 & 0.69 & 0.72 & 0.71 & 0.70 & 0.78 \\
\hline
\end{tabular}

Source: Calculated by the authors

\section{Analysis by Business Classification}

From the perspective of this analysis, it is very interesting to review the drop of the CLR and RLR in comparison to 2007 per industry sector. The results will enable us to determine if the crisis had equally affected all industries or if some industries managed to curb its effects more easily. The sample of 794 companies was divided into industries based on activity code. Then, the liquidity ratios were calculated for each industry individually.

Table 2: Overview of liquidity ratios per industry for the period 2007-2013

\begin{tabular}{|l|c|c|c|c|c|c|c|c|c|}
\hline \multirow{2}{*}{ Industry } & \multirow{2}{*}{$\begin{array}{c}\text { Number of } \\
\text { companies }\end{array}$} & \multicolumn{4}{|c|}{ Current liquidity ratio } & \multicolumn{4}{c|}{ Reduced liquidity ratio } \\
\cline { 3 - 10 } & 2013 & 2011 & 2009 & 2007 & 2013 & 2011 & 2009 & 2007 \\
\hline Agriculture & 31 & 0.93 & 0.85 & 0.99 & 1.18 & 0.58 & 0.49 & 0.56 & 0.84 \\
\hline Mining & 9 & 1.07 & 1.10 & 0.67 & 0.61 & 0.61 & 0.64 & 0.37 & 0.32 \\
\hline $\begin{array}{l}\text { Processing } \\
\text { industry }\end{array}$ & 299 & 1.15 & 1.11 & 1.18 & 1.34 & 0.66 & 0.69 & 0.74 & 0.83 \\
\hline Power supply & 21 & 0.86 & 0.90 & 0.98 & 1.02 & 0.75 & 0.80 & 0.87 & 0.93 \\
\hline Water supply & 24 & 0.92 & 0.91 & 0.90 & 0.99 & 0.73 & 0.71 & 0.71 & 0.74 \\
\hline Construction & 66 & 0.56 & 0.73 & 0.82 & 0.84 & 0.41 & 0.55 & 0.56 & 0.60 \\
\hline Trade & 244 & 1.09 & 1.01 & 1.05 & 1.17 & 0.70 & 0.67 & 0.71 & 0.82 \\
\hline Traffic & 36 & 0.85 & 0.88 & 0.68 & 0.89 & 0.68 & 0.70 & 0.56 & 0.83 \\
\hline $\begin{array}{l}\text { Accommodation } \\
\text { services }\end{array}$ & 4 & 0.35 & 0.30 & 0.43 & 0.87 & 0.29 & 0.25 & 0.36 & 0.80 \\
\hline $\begin{array}{l}\text { Information } \\
\text { sector }\end{array}$ & 19 & 0.82 & 0.79 & 0.99 & 0.92 & 0.82 & 0.71 & 0.86 & 0.84 \\
\hline Crafts & 22 & 1.73 & 1.51 & 1.47 & 1.49 & 1.64 & 1.41 & 1.30 & 1.42 \\
\hline Administration & 12 & 0.51 & 0.61 & 0.46 & 0.55 & 0.48 & 0.59 & 0.44 & 0.56 \\
\hline Entertainment & 7 & 1.51 & 1.30 & 1.20 & 1.15 & 1.31 & 1.13 & 1.01 & 1.02 \\
\hline
\end{tabular}

Source: Calculated by the authors 
What is worrying is the value of liquidity ratio in the construction industry. Both CLR and RLR are the lowest in this industry among all those analyses. Particularly worrying is its trend, which is extremely negative and indicative of the very difficult situation of large companies in this industry. For this reason, we believe that this paper contributes to quantifying and proving that the construction industry has suffered the worst in this economic crisis.

Ratio analysis per industry shows the unequal distribution of the effects of the crisis across industries. What is common to them all is that the liquidity value is lower than at the start of the observed period i.e. at the beginning of 2007. This is just another confirmation that, from the perspective of liquidity, large companies have not yet restored their performance to the pre-crisis level.

\section{Conclusion}

The objective of the research we have conducted was to show the circumstances in which large companies operate in the Republic of Serbia in terms of liquidity. The results obtained by analysing 794 large companies indicate that, at the time of economic crisis (20082010), the observed companies recorded a drop in liquidity. The information for 2011 saw the first significant sign of growth only to drop again in 2012. However, the liquidity of LC in 2013 was on the rise again. By analysing the observed ratios, we have proven the general hypothesis that companies pay particular attention to monitoring and maintaining their liquidity levels during the economic crisis. This fact was proven and more specifically described through analysis of the structure of current assets and through monitoring the share of current assets in total assets of a company. The effects of management's decisions are visible in large companies because the structure of current assets has changed. During the crisis, the supplies are reduced and receivables and cash are increased. However, it is unsettling that the period required to collect receivables has been prolonged which is a telling sign of a difficult situation in which large companies face in regard to their liquidity.

By analyzing liquidity ratios, we noted that their values deviate from the values recommended by theory which is not good and may jeopardize the financial stability of large companies in the future. Still, we have concluded that the RLR has a value which is closer to the one prescribed by theory than CLR, which is a positive fact and indicates that the circumstances have been improving mildly in recent years. By analyzing the liquidity ratios per industries, we have concluded that the not all industries have been affected equally by the economic crisis in terms of liquidity. The hardest hit is the construction industry while entertainment, crafts and trade industries have been least affected. We believe that the results obtained are important and may be viewed as guidelines for future decision both of the state authorities and of the financial management.

\section{References}

Barjaktarović, L. (2009). Upravljanje rizikom. Beograd: Univerzitet Singidunum.

Barjaktarović, L., Jović, Z., \& Milojević, M. (2013). Poslovne finansije. Beograd: Univerzitet Singidunum. 
Barjaktarović, L., Milojević, M., \& Terzić, I. (2014). Results of applience of Benford's law on Serbian companies. SYMORG 2014 (pp. 696-702). Zaltibor: Fakultet organizacionih nauka.

Božilović, S. \& Miletić, V. (2014) Strategije održivog poslovnog rasta preduzeća u uslovima, Ekonomika, 2014 (3), 47-59.

Coderre, D. (2009). Computer - Aided Fraud Prevention and Detection. Hoboicen/New Jersey, John Wileys \& Sons.

Kieso, D., Weygandt, J., \& Warfield, T. (2013). Intermediate Accounting, Hoboicen/New Jersey, John Wileys \& Sons.

Knežević, G., \& Vule, M. (2010). Rizik likvidnosti i njegovo prikazivanje u finansijskim izveštajima. Singidunum revija, 25-36.

Kostič, A., \& Kostić, V. (2014). Svetska ekonomska kriza i zemlje u razvoju, Ekonomika, 2014 (3), 125-137.

Manning, G. (2005). Investigation and Forensic Accounting, Boca Raton, Taylor \& Francis.

Marjanović, V., \& Milojević, M. (2012). Implementation of DEA model in assessment of short term liquidity level of Serbian food-production companies identified as ECR Adopters. Improving the competitiveness of the public and private sector by netcurrent competences (pp. 385-411). Niš: Ekononomski fakultet Niš, Edited by B. Krstić.

Marjanović, V., Milojević, M., \& Simeunović, N. (2011). Značaj pokazatelja likvidnosti i zaduženosti proizvođača hrane i pića u Srbiji i Hravtskoj za sagledavanje strategijskog pozicioniranja. 8. Naučni skup sa međunarodnim učešćem Sinergija 2011 (pp. 269275). Bijeljina: Univerzitet Sinergija.

Milojević, M. (2013). Uticaj stalnih sredstava na poslovanje preduzeća. Beograd: Univerzitet SIngidunum.

Mihajlović, D., Stanković, S., \& Nikolić, M. (2015) Analysis financial balance as base management company, Ekonomika 2015(1), 43-55.

Nigrini, M. (2011) Forensic Analytics Methods and techniques for Forensic Accounting Investigation, Hoboicen/New Jersey, John Wileys \& Sons.

Serbian Business Registers, (2014). Pravilnik o razvrstavanju privrednih društava. Beograd: Republika Srbija.

Schilit, H., \& Perler, J. (2010). Financial Shenanigan How to detect accounting gimmics Fraud in financial reports, New York, McGraw-Hill companies.

Reichmann, T. (2006). Controlling mit Kennzahlen und Management-Tools. Munchen: Franz Vahlen.

Vujević, D. (2010). Globalna finansijska kriza: Poruke i pouke za kasne tranzicione privrede. Beograd: Fakultet za ekonomiju, finansije i administraciju, Univerzitet Singidunum.

Vukašin, L., \& Anđelković, M. (2014) Validity of accounting information for management in the process of decision making, Ekonomika 2014 (4), 165-179.

Wells, J. (2011). Financial Statement Fraud Casebook, Hoboicen/New Jersey, John Wileys \& Sons. 


\section{Endnotes}

3 In literature, these ratios are often call profitability ratios because only items from Income Statement are used in calculation and they do not provide information about the amount of capital engaged.

4 The amounts are presented in Serbian dinars.

5 Liquidity ratios, as an indicator of short-term financial balance, show the company's liquidity only on a specific day and therefore in their interpretation should be careful. 